\title{
Nieeteryczny związek między duchowością chrześcijańską a zdrowiem człowieka
}

\author{
Wiktor Orlof \\ Studenckie Koło Naukowe przy Zakładzie Immunologii Klinicznej UMB \\ Uniwersytet Medyczny w Białymstoku \\ w_orlof@wp.pl \\ Marek Alifier \\ Zakład Immunologii Klinicznej \\ Uniwersytet Medyczny w Białymstoku \\ marek.alifier@umb.edu.pl
}

W. Orlof, M. Alifier, The non-ethereal connection between christian spirituality and human health, Elpis, 20 2018: 119-128.

\begin{abstract}
Health is defined as a state of complete physical, mental and social well-being of a human being, not just a complete absence of disease or disability. Over the years, the basic definition proposed by the WHO has been extended to include another component: the ability to lead an effective social and economic life, as well as the spiritual dimension. The spiritual health of man since the beginning of human consciousness is inseparably connected with the relationship with God. In achieving full health, it is extremely important to achieve a harmonious interaction and coexistence of the spiritual sphere with the physical one. Religious practices are common attempts to create a bridge between the perceivable and measurable state of matter, and the experimental extrasensory spiritual world.

Religious practices have been repeatedly associated with the treatment of different diseases and causing the improvement of physiological parameters may contribute to the actual improvement of human health. Prayer can affect the functioning of the body through various mechanisms. It was found that transcendental meditation with mystical dominance gives significant pro-health effects. Many publications prove that prayer and religious practices have a significant influence in regulating of autonomic, hormonal and mental systems. Practitioners less often suffer from diseases caused by excessive high stress level.

Evidence for a positive correlation between practicing religious practices and measurable parameters, such as level of IL-6, lengths of telomeres, level of CD4 + T cell and mental health, was found. It seems likely that people devoting themselves to religious practices may be characterized by a lower incidence of certain somatic diseases.

The results of the research suggest the need to re-open to other, not only "somatic" forms of therapy, which in a skilful and individualized way should complement the basic methods of therapy currently used. Health care workers, in addition to paying more attention to the spiritual background of existing somatic disorders, should work more closely with psychologists, psychiatrists and clergymen to coordinate a holistic approach to patient care, which should also include aspects of the individual's spirituality.
\end{abstract}

Streszczenie: Zdrowie definiuje się jako stan pełnego fizycznego, umysłowego i społecznego dobrostanu człowieka, a nie wyłącznie całkowity brak choroby czy niepełnosprawności. Z czasem podstawową definicję zaproponowaną przez WHO rozszerzono o kolejne składniki: zdolność do prowadzenia efektywnego życia społecznego i ekonomicznego, a także wymiar duchowy. Zdrowie duchowe człowieka od początku istnienia ludzkiej świadomości nierozerwalnie związane jest relacją z Bogiem. W osiągnięciu pełni zdrowia niezwykle ważne jest osiągnięcie harmonijnego współdziałania i współistnienia sfery duchowej ze sferą cielesną, ich koegzystencji. Praktyki religijne są próbami utworzenia pomostu między postrzegalnym i mierzalnym światem materialnym, a doświadczalnym pozazmysłowo światem duchowym.

Praktyki religijne zostały wielokrotnie powiązywane z leczeniem różnych chorób, a powodując poprawę parametrów fizjologicznych mogą przyczyniać się do faktycznej poprawy zdrowia człowieka. Modlitwa może wpływać na funkcjonowanie organizmu za pomocą różnych mechanizmów. Stwierdzono, że medytacja transcendentalna z dominacją mistyczną daje znaczące efekty prozdrowotne. Wielu publikacji potwierdza, że modlitwa i praktyki religijne mają istotny wpływ na regulację funkcjonowania układu autonomicznego, hormonalnego oraz psychiki. Osoby praktykujące rzadziej chorują na choroby powodowane nadmiernym stresem.

W dotychczas przeprowadzonych badaniach naukowych znaleziono dowody na istnienie korzystnej korelacji pomiędzy uprawianiem praktyk religijnych, a mierzalnymi parametrami biologicznymi np. stężeniem IL 6, długością telomerów, liczbą limfocytów T CD4+ oraz wykładnikami zdrowia psychicznego. Wydaje się prawdopodobne, że osoby oddające się praktykom religijnym mogą charakteryzować się mniejszą częstością niektórych chorób somatycznych.

Wyniki badań sugerują potrzebę ponownego otwarcia się na inne formy terapii, które w umiejętny i zindywidualizowany sposób powinny uzupełniać podstawowe „somatyczne” metody terapii stosowane aktualnie. Pracownicy ochrony zdrowia oprócz zwrócenia uwagi na duchowe tło istniejących zaburzeń somatycznych, powinni ściślej współpracować z psychologami, psychiatrami i duchownymi, w celu skoordynowania holistycznej opieki nad pacjentem, które powinno obejmować także aspekty duchowości jednostki.

Keywords: religion, prayer, meditation, immunology, health

Słowa kluczowe: religia, modlitwa, medytacja, immunologia, zdrowie 
Zdrowie definiuje się jako stan pełnego fizycznego, umysłowego i społecznego dobrostanu człowieka, a nie wyłącznie całkowity brak choroby czy niepełnosprawności ${ }^{1}$. Z biegiem lat podstawową definicję zaproponowaną przez WHO rozszerzono o kolejny składnik, mianowicie o zdolność do ,prowadzenia efektywnego życia społecznego i ekonomicznego" a także wymiar duchowy ${ }^{2}$. Problem duchowego dobrostanu człowieka na przestrzeni życia wpisuje się w istniejący obszerny nurt badań. Sfera duchowa nadaje ton przeżyciom emocjonalnym człowieka oraz wykazuje ścisłą koincydencję z jego funkcjonowaniem poznawczym ${ }^{3}$. Zdrowie duchowe istoty ludzkiej od początku istnienia ludzkiej świadomości nierozerwalnie związane jest relacją człowieka z Istotą Wyższą, z Absolutem, z Bogiem.

Antropologia chrześcijańska zakłada, że człowiek stworzony przez Boga został z dwóch elementów, mianowicie z ciała - czyli pierwiastka doczesnego, ziemskiego oraz pierwiastka eterycznego, nieśmiertelnego - czyli duszy. Dychotomia ciała i duszy koegzystuje z trychotomią (ciało - dusza - duch). Podstawy trychotomii znajdujemy w Piśmie Świętym czytając słowa świętego Pawła: „,sam Bóg pokoju niech was catkowicie uświęca, aby nienaruszony duch wasz, dusza i ciało bez zarzutu przygotowaty się na przyjście Pana naszego Jezusa Chrystusa" (1Tes $5,23)^{4},{ }^{5}$, . Szeroko o tym problemie pisał Orygenes ${ }^{6}$, dla którego słowa apostoła były absolutnie wiążące ${ }^{7}$. Dusza ożywia ciało, czyni je „duszą żyjącą”, a duch „uduchowia” całą istotę ludzką. Innymi słowy pierwiastek nieśmiertelny, czyli dusza, „ożywia” i nadaje wartość oraz sens pierwiastkowi doczesnemu, jakim jest ciało. Duch, będąc kategorią religijną, jest zasadą, która kwalifikuje, podkreśla, na wszystkim kładzie piętno innego bytu. Wyraża się poprzez psychiczność, jak i materialność, ubarwiając je swym jestestwem. Co duchowe, czyli to co związane z duszą, nie powinno być rozpatrywane jako trzecia płaszczyzna (czy inaczej trzecie piętro) struktury bytu. To, co wynika z ducha, pierwiastka boskiego, jest zasadą, która się wyraża poprzez to, co psychiczne, i przez to, co cielesne, czyniąc oba te elementy duchowymi ${ }^{8}$.

\footnotetext{
Definicja za konstytucją Światowej Organizacji Zdrowia (World Health Organisation - WHO) z 1946 r.

2 Chuengsatiansup, K. (2003). Spirituality and health: an initial proposal to incorporate spiritual health in health impact assessment. Environmental Impact Assessment Review, 23, 3-15.

Heszen-Niejodek, I., Gruszczyńska, E. (2004). Wymiar duchowy człowieka, jego znaczenie w psychologii zdrowia i jego pomiar. Przegląd psychologiczny, 47(1), 15-31.

4 Cytaty i sigla Pisma Świętego pochodzą z Biblii Jerozolimskiej.

Po za ciałem (Rz 7,24) i duszą (1Kor 15,44$)$ pojawia się tu - jak widać także duch, który może być postrzegany jako Boża zasada nowego życia w Chrystusie (Rz 5,5+) lub raczej jako najwyższa sfera człowieka, właśnie ta otwarta na działanie Ducha (Rz 1.9+). Akcent spoczywa na obejmującej wszystko pełni skutków uświęcającego działania Boga, działania, będącego konsekwencją jego wierności.

Orygenes (żył ok. 185-254) - jeden z najbardziej płodnych komentatorów Pisma Świętego w epoce patrystycznej.

Turzyński, P. (2015). Antropologia trychotomiczna Orygenesa. VOX PATRUM, 63, 35-46.

8 Evdokimov, P. (1986). Prawosławie. Warszawa: Instytut Wydawniczy PAX, 81-84.
}

W osiągnięciu pełni zdrowia niezwykle ważne jest osiągnięcie harmonijnego współdziałania i współistnienia sfery duchowej ze sferą cielesną, ich harmonijnej i współbieżnej koegzystencji. Co niezwykle istotne, do osiągniecia pełni dobrostanu niezbędne wydaje się zrozumienie i akceptacja własnych ograniczeń, tak duchowych, jak cielesnych. Wielu ludziom pomagają w osiągnięciu tego stanu różnorodne praktyki religijne, wśród których należy przede wszystkim wspomnieć o modlitwie i medytacji. Według wielu teologów chrześcijańskich praktyki religijne mogą, a nawet muszą stać się tym samym dla rozwoju naszej sfery duchowej, czym stały się ćwiczenia fizyczne dla naszego stanu fizycznego". Innymi słowy niezbędna jest pewnego rodzaju forma „ćwiczeń” duchowych, „treningu” duszy by osiągnąć stan pełnej harmonii pomiędzy najważniejszymi pierwiastkami ludzkiego życia.

Arystoteles ${ }^{10}$ podkreślał jedność duszy i ciała, ich nierozłączność i konieczność rozpatrywania jako całości. Ewagariusz ${ }^{11}$ z Pontu rozważał i poddawał analizie związki duszy z ciałem a także popędy i namiętności. Rozważania, prowadzące do zguby człowieka, a które są trzonem jego postępowań, określił logisimoi. Ewagariusz wyodrębnił osiem logisimoi, są nimi choroby ducha, które mogą objawiać się poprzez choroby somatyczne. W swoim traktacie służy radą, jak wzbić się na wyżyny duchowe, co zrobić by osiągnąc stan bliski ideałowi określany jako apatheia (termin nie znaczy tego co współczesna apatia) stan pozbawiany zachowań patologicznych. Stan ten św. Jan Damasceński określił jako powrót od tego, co przeciw naturze, do tego, co jest jej należne, zatem beznamiętność nie polega na nieodczuwaniu namiętności lecz na ich nie przyjmowaniu $^{12}$.

Święty Paisjusz (Hagioryta) mawiał, że „,Musimy czuć potrzebę modlitwy. Tak jak ciatu, żeby żyć, potrzebny jest pokarm, tak samo dusza, żeby żyć, musi się odżywiać. Jeśli nie będzie się odżywiać, ostabnie, a potem nastapi duchowa śmierć"13. Klasyczne formy modlitwy obejmują m.in czytanie Psalmów, które to „słowo Pism wzmacnia duszę i odpędza demony"14. Wszelki liryzm tekstów modlitw jest surowo oczyszczony, aby uzyskać jasność i trzeźwość myśli; innymi słowy: by w modlitwie podążać czystą myślą za Chrystusem. Prosta myśl skupiona na Stwórcy pozwala modlącemu na zjednoczona z Bogiem. Dokonując zintegrowania swego bytu duchowego np. poprzez ascezę, modlący się (w szczególności mistyk) stawia w centrum życia płomienną modlitwę, której najgłębszym wyrazem jest „modlitwa Jezusowa"15. W tej modlitwie znajduje się idea całej Ewangelii, a jednocześnie w swej prostocie poprzez

\footnotetext{
Śliwerski, B. (2007). Samowychowanie jako odrodzenie moralne. Przegląd pedagogiczny, 1, 15-34.

10 Arystoteles (ur. 384 p.n.e., zm. 322 p.n.e.) - filozof, jeden z trzech obok Sokratesa i Platona - najsławniejszych filozofów starożytnej Grecji. 11 Ewagriusz z Pontu (ur. 345 n.e., zm. 399 n.e.) - mnich pontyjski, teo$\log$, mistyk. Jeden z najznamienitszych ojców pustyni.

12 Centurie Kaliksta i Ignacego w: Filokalii.

13 Jakimiuk, M. (red.) (2016). Święty starzec Paisjusz Hagioryta - Słowa wybrane fragmenty. Hajnówka: Bratczyk.

14 Św. Nil Synaita, De oratione.

15 Panie Jezu Chryste, Synu Boży, zmituj się nade mną grzesznym.
} 
wyznanie panowania Chrystusa, Jego Boskiego Synostwa, a więc Trójcy Świętej daje świadectwo jedności różnych bytów, w których przejawiał się Chrystus. Modlitwa ta ma charakter trynitarny: gdy wzywamy Chrystusa, nawołujemy równoczasowo Ojca i Ducha, bo gdzie obecny jest Syn tam też jest Ojciec i Duch ${ }^{16}$. Kolejno Modlitwa Jezusowa odnosi się do głębi upadku; i wreszcie następuje wezwanie do Bożego miłosierdzia ${ }^{17}$.

Człowiek nie rodzi się jako istota w pełni zharmonizowana w sferach ducha, psychiki i ciała. Owe rozbicie, wg teologii chrześcijańskiej, stanowi następstwo grzechu pierworodnego - jak za świętym Pawłem (1Kor 5, 3-5) ${ }^{18}$ w swym traktacie o duszy pisał św. Augustyn ${ }^{19}$ : ,czlowiekiem nie jest samo ciało albo sama dusza, lecz to, co jest złożone z duszy i z ciata". Brak tej harmonii można próbować usunąć. W celu przywrócenia integralności swej istoty człowiek powinien dążyć do poznania Boga przez praktyki religijne. Według kanonu myśli chrześcijańskiej, to właśnie intensywna wiara daje możliwość przywrócenia właściwej roli duszy w życiu człowieka. Sakramenty odtwarzają pierwotną naturę człowieka, gdyż Duch Święty, dany pierwszemu człowiekowi „razem z życiem”, zostaje nam także udzielony przez chrzest i potwierdzony w bierzmowaniu. Brak tej swoistej trójharmonii, może powodować różnorodne zaburzenia duszy, zaburzenia duszy mają zaś swoje odbicie w chorobach ciała. Próby naprawy nie w pełni funkcjonalnej sfery duchowej są w swej istocie, także jedną z form rekonwalescencji ciała. Pokuta spełnia nie tylko funkcje stricte duchową, ale, z pragmatycznego punktu widzenia, u ludzi wierzących, pełni funkcję terapeutyczną. Eucharystia wprowadza zaczyn nieśmiertelności ${ }^{20}$; człowiek nie jest bytem, który może bezkarnie grzeszyćc ${ }^{21}$.

Co więcej ten pogląd wydaje się być zadziwiająco zbieżny z poglądami współczesnej medycyny, która do osiągnięcia zdrowia zakłada konieczność nie tylko współistnienia ciała i duszy, ale również ich efektywnej współpracy, której jakość zależy od całościowej integracji procesów fizjologicznych i duchowych. Po okresie wyparcia przez nauki medyczne czynnika religijnego w diagnostyce i leczeniu pacjentów mamy dzisiaj renesans postrzegania tego problemu i coraz częściej artykuły naukowe, a w nich badacze postulują uwzględnienie sfery duchowej w procesach leczniczych ${ }^{22}$.

\footnotetext{
16 Ałfiejew, H. (2009). Misterium wiary. Wprowadzenie do Prawosławnej teologii dogmatycznej. Warszawa: Warszawska Metropolia Prawosławna, 223.

17 Evdokimov, P. (1986). Prawostawie. Warszawa: Instytut Wydawniczy PAX, 146-148.

18 Cytaty i sigla Pisma Świętego pochodzą z Biblii Jerozolimskiej.

19 Świderkówna, A. (tłum.). (2002). Św. Augustyn. Dialogi duszy. Kraków: Znak.

20 Plany: kosmiczny, ludzki i anielski łączą się w jednej Eucharystii: „Tyś z niebytu do istnienia nas wprowadził i nie przestałeś działać, aż nas do nieba podniosłeś i darowałeś nam przyszłe Królestwo". Poprzez grzech oddala się nasza szansa zjednoczenia z Bogiem na wiecznej Eucharystii. Pokuta przywraca eucharystyczną jedność.

21 Evdokimov, P. (1986). Prawostawie. Warszawa: Instytut Wydawniczy PAX, 118.

22 Pietkiewicz, P. (2016). Wspótpraca kapłana i psychiatry w celu przywrócenia zdrowia człowieka. Elpis, 18, 133-136.
}

W teologii chrześcijańskiej pozycja Boga, zarówno w procesach zdrowienia, jak też podtrzymywania stanu zdrowia, jest zdefiniowana bardzo jasno. Bóg jest, i chce być lekarzem człowieka (Wj 15, 26) ${ }^{23}$. Znaczącym jest fakt, że imię archanioła, które wskazuje kierunek, podążając którym można uzyskać zdrowie, brzmi Rafał, co znaczy w języku hebrajskim „Bóg uzdrawia” (Tb 3, 17) ${ }^{24}$. Co więcej rola lekarza również jest jasno sprecyzowana: lekarz i metody przez niego użyte służące do uzdrawiania są narzędziami w rękach Boga: Szanuj lekarza za jego ustugi, jego też stworzyt Pan. Uzdrowienie pochodzi od najwyzszego i od króla lekarz otrzymuje dary. [...] Pan stworzyt lekarstwa pochodzace z ziemi i roztropny czlowiek nie będzie ich odrzucat. [...] (Syr 39 1-2 i 4) $)^{25}$.

\section{Sprawny system immunologiczny warunkiem zdrowia}

Koenig i in. (2012), zwracają uwagę, że aby zdać sobie sprawę w jaki sposób religia wywiera wpływ na system immunologiczny ważnym jest poznanie jak ów system funkcjonuje ${ }^{26}$. Jest to niezwykle ważne w sytuacji, gdy organizm człowieka wykazuje daleko idącą biologiczną odrębność i posiada wysoki stopień autonomii względem środowiska, którego jest częścią. Podstawową funkcją układu immunologicznego jest ochrona przed infekcjami i patogenami je wywołującymi, ale również ochrona przed różnego rodzaju zagrożeniami wewnątrzustrojowymi (m.in. eliminacja komórek ulegających transformacji nowotworowej). Człowiek w celu ochrony własnego istnienia, aby zachować równowagę ze środowiskiem zewnętrznym, utworzył $\mathrm{w}$ procesie filogenetycznym zabezpieczenia przed niepożądanym wpływem czynników zewnętrznych. Organizm człowieka posiada dwie, tradycyjnie wyróżniane, linie obrony immunologicznej: pierwsza to odporność nieswoista (wrodzona, zwykle niezmienna, ukształtowana wskutek wielu tysięcy lat immunologicznych doświadczeń naszych przodków); druga, ze względu na swój wybiórczy i adoptatywny charakter nazwana odpornością swoistą (nabywana w trakcie życia, wskutek naszych osobniczych doświadczeń $)^{27}$.

Odporność wrodzona stanowi główną oraz natychmiastową zaporę przed wniknięciem patogenów oraz np. niektórych toksyn. Na ochronę tą składają się bariery fizyczne takie jak skóra, śluzówki, czy wydzieliny pokrywające układy mające bezpośredni kontakt ze światem zewnętrznym. Podczas gdy patogen próbuje pokonać bariery fizykochemiczne, organizm broni się przy użyciu innych immunologicznych substancji, takich jak białka przeciwbakteryjne czy białka regulacyjne. Niezwykle istotne

\footnotetext{
23 Zob. Biblia Jerozolimska

$24{ }^{24}$ Tamże.

$25 \quad 25$ Tamże.

26 Koenig, H.G., King, D.A., Carson, V.B. (2012). Handbook of Religion and Health. New York: Oxford University Press, 15.

27 Wolański, N. (2012). Rozwój biologiczny człowieka. Podstawy auksologii, gerontologii i promocji zdrowia. Warszawa: PWN, 436-445.
} 
W procesie obrony immunologicznej są substancje zwane cytokinami, które przekazując chemiczne sygnały między składowymi układu immunologicznego, pośredniczą w działaniu innych składowych układu odpornościowego. Znaczące grupy cytokin to m.in. interferony, czynniki hemopoetyczne, interleukiny, chemokiny, czy nadrodzina cząstek TNF ${ }^{28}$. Do nieswoistych, komórkowych mechanizmy obrony zaliczamy m.in. neutrofile, monocyty, makrofagi czy komórki NK.

Odporność nabyta, czyli swoista dla każdego z nas, polega na specyficznej reakcji obronnej komórek wobec obcych antygenów. Taka nabyta odpowiedź immunologiczna jest zależna od sprawności np. komórek prezentujących antygen oraz innych (m.in. limfocytów T i B). Komórki prezentujące obce antygeny pobudzają limfocyty $\mathrm{T}$ (generalnie odpowiedzialnych za odpowiedź komórkową) i/lub limfocyty B (generalnie odpowiedzialnych odpowiedź humoralną - związaną z wytwarzaniem przeciwciał). W odpowiedzi typu komórkowego limfocyty $\mathrm{T}$ są odpowiedzialne za zniszczenie przede wszystkim, ale nie wyłącznie, wewnątrzkomórkowych patogenów. W odpowiedzi typu humoralnego limfocyty B, różnicujące się w kierunku komórek produkujących przeciwciała, przeciwko specyficznym antygenom. Warto zauważyć, że efekty mobilizacji nabytej humoralnej odpowiedzi komórkowej są skierowane głównie przeciwko patogenom zewnątrzkomórkowym ${ }^{29},{ }^{30}$.

\section{Czynniki biologiczne wywierające wpływ na system immunologiczny}

Czynniki biologiczne mogące determinować powstawanie i przebieg schorzeń o podłożu niedomogi immunologicznej mogą być uwarunkowane dziedziczne i mogą się objawiać pod postacią niedoborów odporności czy chorób autoimmunologicznych. Integralność oraz prawidłowe funkcjonowanie systemu odpornościowego mogą zaburzać czynniki infekcyjne, czynniki toksyczne, alkohol, palenie papierosów, marihuany czy inne używki zaburzają prawidłowe funkcjonowanie układu odpornościowego ${ }^{31}$.

\footnotetext{
28 Interferon (INF) - wykazuje właściwości przeciwwirusowe, immunomodulujące oraz antyproliferacyjne. Aktywuje komórki NK ważne w procesie niszczenia komórek zakażonych wirusami oraz nowotworowych. Interleukiny - umożliwiają kontakt między komórkowymi komponentami układu odpornościowego; niektóre wywołują działanie ogólnoustrojowe. Chemokiny - aktywują, przyciągają oraz kierują funkcjonowaniem wielu komórek odpornościowych. Czynniki martwicy nowotworów - neutralizują komórki nowotworowe oraz stymulują proces zapalny. 29 Irving, W., Ala'Aldeen, D., Boswell, T. (2005). BIOS Instant notes in Medical Microbiology. New York: Taylor and Francis Group, 9-17.

30 Salomon, E.P., Berg, L.R., Martin, D.W. (2009). Biologia. Warszawa: Multico, 831-856.

31 Koenig, H.G., King, D.A., Carson, V.B. (2012). Handbook of Religion and Health. New York: Oxford University Press, 396.
}

\section{Czynniki psychologiczne wywierające wpływ na system immunologiczny}

W ciągu kilkunastu ostatnich lat pojawily się doniesienia traktujących o wpływie czynników psychologicznych na funkcjonowanie układu immunologicznego $0^{32}, 33$.

W sytuacjach patologicznych, które dość często mogą być indukowane przez czynniki emocjonalne i mogą być związane z aktualnym stanem psychicznym człowieka, może dojść do nieprawidłowej aktywności układu immunologicznego, co przyczynić się może do znacznego osłabienia odporności i rozwoju choroby zakaźnej bądź nowotworowej lub paradoksalnie, takie zaburzenia sfery psyche mogą spowodować nadmierną reakcję immunologiczną i spowodować rozwój chorób z autoagresji ${ }^{34}$.

Badania nad osobami wykorzystywanymi seksualnie i osobami z zespołem stresu pourazowego sugerują, że mają długotrwale podwyższony poziom hormonów stre$\mathrm{su}^{35}$. Podobne zjawisko obserwuje się u uczniów w czasie egzaminu ${ }^{36}$. Fizjologiczne następstwa tego typu zmian hormonalnym są różnorodne. Przewlekle utrzymujące się podwyższone stężenie hormonu stresu, jakim jest kortyzol, $\mathrm{z}$ jednej strony osłabia zdolność do obrony przed infekcjami, $\mathrm{z}$ drugiej zaś sprzyja m.in. nasileniu objawów alergii. Collingwood (2016) ${ }^{37}$, podaje wiele dowodów na fakt wzmacniania układu odpornościowego przez pozytywne emocje, a hamowania go przez negatywne. Podaje, że w grupie studentów jak i innych osób doświadczających samotności, złości, czy traumy, zakażenia ran leczą się statycznie dłużej. W grupach osób mających pozytywne i głębokie relacje z przyjaciółmi i rodziną ich emocje wydają się mieć odwrotny, wzmacniający wpływ na system odpornościowy.

Znanym jest fakt, że kontakty społeczne i śmiech, praktyki religijne mają wymierny wpływ antystresowy ${ }^{37}$. Relaks poprzez masaż lub słuchanie muzyki zmniejsza również hormony stresu ${ }^{38},{ }^{39}$.

Zmiany stanu psychicznego w bezpośredni sposób wpływają na wiele aspektów działania układu immuno-

\footnotetext{
McEwen, B.S., Stellar, E. (1993). Stress and the individual. Mechanisms leading to disease. Arch Intern Med., 153(18), 2093-2101.

33 McEwen, B.S. (2007). Physiology and neurobiology of stress and adaptation: central role of the brain. Physiol Rev., 87(3), 873-904.

34 D'Acquisto, F. (2017). Affective immunology: where emotions and the immune response converge. Dialogues in Clinical Neuroscience, 19(1), 9-19.

35 Cahill, S. P., Pontoski, K. (2005). Post-Traumatic Stress Disorder and Acute Stress Disorder I: Their Nature and Assessment Considerations. Psychiatry (Edgmont), 2(4), 14-25.

36 Al-Ayadhi, L.Y. (2005). Neurohormonal changes in medical students during academic stress. Ann Saudi Med., 25(1), 36-40.

37 Collingwood, J. (2016). How Does Mood Affect Immunity?. Psych Central. Retrieved on March 15, 2017.

38 Peale, N.V. (2002). Moc pozytywnego myślenia. Warszaw: Wydawnictwo Studio Emka, 54-70.

39 Paloutzian, R.F., Park, C.L. (2005). Handbook of the psychology of religion and spirituality. New York: Guilford Press, 12.
} 
logicznego, zarówno w sposób bezpośredni jak i pośredni. Stany takie jak 'depresja, stres i lęk' ${ }^{32-35}$ wpływają na nadmierne uwalnianie przez podwzgórzowe ośrodki mózgowe hormonu kortykoliberyny. Oprócz bezpośrednich wpływów tego hormonu na ośrodki zawiadujące zachowaniem człowieka (m.in. uaktywnianie zachowań lękowych, hamowanie apetytu czy aktywności seksualnej), jest to jeden z najsilniejszych czynników hormonalnych stymulujących przysadkę do wydzielania hormonu adrenokortykotropiny. Kolejna konsekwencją tej kaskady efektów biologicznych związanych ze zmianą stanu psychicznego jest stymulacja kory nadnerczy i następowe uwalnianie kortyzolu. Stres jest również czynnikiem bezpośrednio stymulującym nadnercza do uwalniania katecholamin ${ }^{40}$. Hormony te działając krótkoterminowo mobilizują organizm do zwiększonego metabolizmu. Długoterminowe ich uwalnianie sprzyja pojawieniu się chorób takich jak np. astma, cukrzyca, choroby przewodu pokarmowego, zapalenie serca, nadciśnienie, nowotwory, infekcje wirusowe, choroby autoimmunologiczne, a także łuszczycy czy innych zmian skórnych ${ }^{41}, 26$.

Chociaż zwiększona zachorowalność i śmiertelność wydają się być związane z izolacją społeczną i mniej satysfakcjonującymi związkami osobistymi, to stosunkowo niewiele wiadomo o podstawowych mechanizmach rządzących tymi zależnościami. Kiecolt-Glaser i in. (1993), analizowali wpływ stresu na układ immunologiczny ${ }^{42}$ w dość selektywnie wybranej populacji nowożeńców. Pary zostały wybrane na podstawie rygorystycznych kryteriów zdrowia psychicznego i fizycznego. Autorzy oceniali zachowania związane $\mathrm{z}$ rozwiązywaniem problemów i zmianami w funkcjonowaniu układu odpornościowego u 90 nowożeńców, którzy zostali przyjęci do szpitala na co najmniej $24 \mathrm{~h}$ obserwację. Wykazano negatywne skutki dla odporności już po 30 minutach kłótni małżeńskiej. Pacjenci, którzy wykazywali bardziej negatywne lub wrogie zachowania po dyskusji na temat problemów małżeńskich w ciągu 24 godzinne obserwacji szpitalnej, wykazywali statystycznie większe nieprawidłowości w czterech funkcjonalnych testach immunologicznych. Stwierdzono między innymi występowanie podwyższonego ciśnienia krwi, a z parametrów stricte immunologicznych m.in. spadek aktywności komórek NK, zmniejszoną ilość przeciwciał w związku z tzw. downregulation układu immunologicznego. Pozytywne lub wspierające się zachowania w trakcie rozwiązywania problemów nie były związane ze zmianami immunologicznymi. Te różnice fizjologiczne były szczególnie godne uwagi, ponieważ satysfakcja (zgodność) małżeńska była wysoka w obu grupach przed kłótnią. Paca powyższa stanowi doskonały przykład dowodów na istnienie bezpośredniego i szybkiego związku pomiędzy niepra-

\footnotetext{
40 Breen, M.S., Beliakova-Bethell, N., Mujica-Parodi, L.R., Carlson, J.M., Ensign, W.Y., Woelk, C.H., Rana, B.K. (2016). Acute psychological stress induces short-term variable immune response. Brain Behav Immun., 53, 172-182. doi: 10.1016/j.bbi.2015.10.008.

${ }_{41}$ McEwen, B.S., Stellar, E. (1993). Stress and the individual: Mechanisms leading to disease. Archives of Internal Medicine, 153, 2093-2101.
}

widłowościami w nastroju człowieka, a stanem układu immunologicznego ${ }^{42}$.

\section{Mechanizmy wpływu modlitwy na proces uzdrawiania Efekty fizjologiczne modlitwy i medytacji}

Praktyki religijne zostały wielokrotnie powiązywane $z$ leczeniem wszelakich chorób przez tysiąclecia ${ }^{43}$. Ludzie modlą się o dobre zdrowie lub proszą o uzdrowienie z choroby. Istnieje wiele przekonywujących dowodów naukowych sugerujących, że modlitwa może przyśpieszać lub wręcz indukować uzdrowienia ${ }^{44}$. Jej wpływ opisywany jest jako udział kilku mechanizmów ${ }^{43,44}$.

Modlitwa jest specjalną formą medytacji, może więc powodować wszelkie korzyści zdrowotne, które są związane z medytacją. U medytujących wykazano psychologiczne i biologiczne efekty, które są faktycznie lub potencjalnie związana z poprawą stanu zdrowia ${ }^{44}$. Fizjologiczne skutki płynące z medytacji są różnorodne.

Medytacja wpływa na obniżenie spoczynkowego (siedzącego) i ambulatoryjnego (analiza 24h) ciśnienia krwi tętniczej i czynności serca w sposób istotny statystycznie ${ }^{45}$. W badaniu przeprowadzonym przez Barnes'a $i$ in. (2004), grupy medytacyjne zobowiązane były do 10-minutowej sesji w szkole i w domu po szkole każdego dnia przez 3 miesiące. Badacze wykazali, że regularne praktykowanie medytacji może potencjalnie obniżać skurczowe i rozkurczowe ciśnienie krwi odpowiednio o około 4,7 i $3,2 \mathrm{mmHg}^{46}$ jak twierdzą Anderson i in. (2008). Wartości te są istotne z klinicznego punktu widzenia. Co ważne, medytacja szybciej i bardziej intensywnie niż zwykły fizyczny odpoczynek zmniejsza częstości skurczów serca, co opisali Solberg i in. (2004a) ${ }^{47}$. Wyniki otrzymane przez w/w badaczy były porównywalne do opublikowanych przez Anderson i in. (2008).

Modlitwa medytacyjna oraz medytacja transcendentalna wpływają na zmianę stężenia ważnych neuroprzekaź-

42 Kiecolt-Glaser, J.K., Malarkey, W.B., Chee, M., Newton, T., Cacioppo, J.T., Mao, H.Y., Glaser, R. (1993). Negative behavior during marital conflict is associated with immunological down-regulation. Psychosom Med., 55(5), 395-409.

43 Woźniak, B. (2015). Zaangażowanie religijne a zdrowie w starości Mechanizmy zależności, wybrane wyniki badań. Kraków: Wydawnictwo Uniwersytetu Jagiellońskiego.

44 Schwartz, S.A., Dossey, L. (2010). Nonlocality, intention, and observer effects in healing studies: laying a foundation for the future. Explore (NY)., 6(5), 295-307. doi: 10.1016/j.explore.2010.06.011.

45 Barnes, V.A., Davis, H.C., Murzynowski, J.B., Treiber, F.A. (2004). Impact of meditation on resting and ambulatory blood pressure and heart rate in youth. Psychosom Med., 66(6), 909-914.

46 Anderson, J.W., Liu, C., Kryscio, R.J. (2008). Blood pressure response to transcendental meditation: a meta-analysis. Am J Hypertens, 21(3), 310-366. doi: 10.1038/ajh.2007.65.

47 Solberg, E.E., Ekeberg, O., Holen, A., Ingjer, F., Sandvik, L., Standal, P.A., Vikman, A. (2004a). Hemodynamic changes during long meditation. Appl Psychophysiol Biofeedback, 29(3), 213-321. 
ników m.in. melatoniny i serotoniny ${ }^{48}$. Odkrycia Solberg $i$ in. (2004b), sugerują, że osoby zaawansowane w medytacji mają wyższy poziom melatoniny niż osoby nie medytujące. Stężenie melatoniny obniża się podczas długotrwałej medytacji, ale wciąż pozostaje na poziomie wyższym niż w grupie kontrolnej (u osób niemedytujących). Stężenie serotoniny zmniejsza się po jednogodzinnej medytacji i odpoczynku (Solberg i in., (2004b)). Autorzy sugerują, że serotonina może być markerem ogólnego odpoczynku, a nie relaksacji opartej na medytacji. Obecne wyniki potwierdzają, że medytacja może wpływać na neuroprzekaźniki, chociaż szczegółów tego, w jaki sposób się to odbywa, nie udało się do tej pory wyjaśnić. Funkcje melatoniny są różnorodne. Melatonina między innymi koordynuje funkcjonowanie nadrzędnego chronometru biologicznego, regulującego biorytmy dobowe np. snu i czuwania u ssaków w tym u ludzi. Prócz regulowaniem rytmów dobowych melatonina ma jednocześnie korzystny wpływ na system odpornościowy. Jest także silnym antyoksydantem ${ }^{49}$. Podanie melatoniny $\mathrm{w}$ nowotworach trzustki indukuje ich apoptozę ${ }^{50}$ czyli śmierć komórek nowotworowych poprzez immunologiczną ,autodestrukcję”. Wysoki poziom melatoniny u praktykujących medytację duchową może mieć ochronny wpływ antynowotworowy (przypis autorów).

Kjaer i in. (2002), stosując specjalistyczna metodę obrazowania aktywności mózgu przy użyciu PET-rakloprid $\mathrm{z}$ izotopem węgla $11 \mathrm{C}$, wykazali zwiększone uwalnianie dopaminy endogennej w prążkowiu brzusznym podczas medytacji ${ }^{51}$. Opisali oddziaływanie medytacji na hamowanie kortykostrialnego przekaźnictwa glutaminergicznego ${ }^{52}$ w regionie korowo-prążkowym. Sugeruje się, że bycie w świadomym stanie medytacji powoduje zahamowanie transmisji glutaminergicznej korowo-prążkowanej ${ }^{51}$. Wykazano, że nadmiar glutaminianu wpływ cytotoksyczny na neurony, co opisano przede wszystkim na przykładzie chorób neurodegeneracyjnych ${ }^{53}$. Co za tym idzie medytacja

\footnotetext{
48 Solberg, E.E., Holen, A., Ekeberg, Ø., Østerud, B., Halvorsen, R., Sandvik, L. (2004b). The effects of long meditation on plasma melatonin and blood serotonin. Med Sci Monit., 10(3), 96-101.

49 Pandi-Perumal, S.R., BaHamman, A.S., Spence, D.W., Brown, G.M., Bharti, V.K., Kaur, C., Hardeland, R., Cardinali, D.P. (2012). Melatonin antioxidative defense: therapeutical implications for aging and neurodegenerative processes. Neurotoxicity Research, 23(3), 267-300.

50 Jaworek, J., Leja-Szpak, A., Nawrot-Porąbka, K., Szklarczyk, J., Kot, M., Pierzchalski, P., ... Bonior, J. (2017). Effects of Melatonin and Its Analogues on Pancreatic Inflammation, Enzyme Secretion, and Tumorigenesis. International Journal of Molecular Sciences, 18(5), 1014. http:// doi.org/10.3390/ijms18051014.

51 Kjaer, T.W., Bertelsen, C., Piccini, P., Brooks, D., Alving, J., Lou, H.C. (2002). Increased dopamine tone during meditation-induced change of consciousness. Brain Res Cogn Brain Res., 13(2), 255-259.

52 Kwas glutaminowy jest głównym neuroprzekaźnikiem pobudzającym ośrodkowego układu nerwowego. Wykorzystywany jest przez około połowę neuronów mózgu. Kwas glutaminowy odgrywa zasadniczą rolę w dojrzewaniu neuronów, regulując ich podziały i migrację w czasie rozwoju układu nerwowego, pełni ważne funkcje w procesach powstawania pamięci i uczenia się oraz wielu innych (m.in. reguluje przewodzenie czucia bólu w rdzeniu kręgowym i mózgu).

53 Permoda-Osip, A., Rybakowski, A. (2011). Rola układu glutaminergicznego $w$ mechanizmie działania przeciwdepresyjnego i normotymicznego w chorobach afektywnych. Farmakoterapia w psychiatrii i neurologii, 2, 57-65.
}

może w takich sytuacjach pełnić funkcję neuroprotekcyjną (przypis autorów).

Davidson $\mathrm{i}$ in. (2003), przeprowadzili randomizowane, kontrolowane badanie wpływu na mózg i funkcję immunologiczną 8-tygodniowego programu medytacji ${ }^{54}$. Badacze mierzyli aktywność elektryczną mózgu przed i zaraz po, a następnie 4 miesiące po 8-tygodniowym programie treningowym. Dwadzieścia pięć osób zostało zakwalifikowanych i testowanych w grupie medytacyjnej. Grupa kontrolna liczyła 16 osób, była testowana w tych samych punktach czasowych, co medytujący. Pod koniec badania w obu grupach uczestnicy zostali zaszczepieni szczepionką przeciwko grypie. Autorzy dowiedli wzrostu aktywności bioelektrycznej w obrębie półkuli dominującej (u osób praworęcznych - półkuli lewej), u osób medytujących, w porównaniu z niemedytującymi. Stwierdzili także znaczący wzrost miana przeciwciał powstałych wskutek podaży szczepionki przeciwko grypie wśród osób uczestniczących w medytacji, w porównaniu z grupą kontrolną. Badania te dały przyczynek do stwierdzenia, że nawet stosunkowo krótki program medytacji daje widoczne efekty na funkcjonowanie mózgu i układu odpornościowego ${ }^{54}$.

Niezależne grupy badaczy dowiodły, że medytacja duchowa przewyższa świecką medytację i relaksację w kategoriach zmniejszenia lęku i poprawy nastroju, zdrowia duchowego, duchowych doświadczeń i tolerancji na ból $1^{55},{ }^{56}$. Praktykowanie medytacji duchowej w znacząco większy sposób zmniejsza częstość występowania migrenowych bólów głowy, lęków i negatywnych afektów, zaś modlitwa medytacyjna zwiększa tolerancję bólu ${ }^{57}$.

Wahbeh i in. (2018), ocenili wpływ m.in. chrześcijańskiej medytacji transcendentalnej na wyniki elektroencefalografii (EEG), elektrokardiografii, elektromiografii, elektrookulogramu, potencjałów związanych z zdarzeniami, funkcjonalnego obrazowania metodą rezonansu magnetycznego, magnetoencefalografii, oddychania oraz przewodnictwa i reakcji skórnych. Stany transcendentalne najbardziej konsekwentnie kojarzyły się ze spowolnionym oddychaniem, zawieszeniem oddechowym, zmniejszoną aktywnością mięśni i blokowaniem EEG fal alfa wraz z zewnętrznymi bodźcami, a także zwiększoną mocą fal alfa EEG, spójnością EEG i funkcjonalną łącznością neuronalną. Stan transcendencji opisywany jest jako stan spokojnego czuwania w fenomenologicznie różnej czasoprzestrzeni ${ }^{58}$.

\footnotetext{
54 Davidson, R.J., Kabat-Zinn, J., Schumacher, J., Rosenkranz, M., Muller, D., Santorelli, S.F., Urbanowski, F., Harrington, A., Bonus, K., Sheridan, J.F. (2003). Alterations in brain and immune function produced by mindfulness meditation. Psychosom Med., 65(4), 564-570.

55 Wachholtz, A.B., Pargament, K.I. (2005). Is spirituality a critical ingredient of meditation? Comparing the effects of spiritual meditation, secular meditation, and relaxation on spiritual, psychological, cardiac, and pain outcomes. J Behav Med., 28(4), 369-384.

56 Andrade, C., Radhakrishnan, R. (2009). Prayer and healing. A medical and scientific perspective on randomized controlled trials. Indian J Psychiatry, 51, 247-253.

57 Wachholtz, A.B., Pargament, K.I. (2008). Migraines and meditation: does spirituality matter? J Behav Med., 31(4), 351-366. doi: 10.1007/ s10865-008-9159-2.

58 Wahbeh, H., Sagher, A., Back, W., Pundhir, P., Travis, F. (2018).
} 


\section{Bezpośredni wpływ na wykładniki intensywności procesów immunologicznych Religia a poziom interleukiny
6 (IL-6)}

Interleukina 6 (IL-6) jest jedną z cytokin niezbędnych dla prawidłowego funkcjonowania układu immunologicznego. Wykazuje działanie wielokierunkowe (plejotropowe), wpływając zarówno na składowe układów odporności wrodzonej i nabytej, ale powodując też wiele reakcji ogólnoustrojowych. Wpływając na ośrodek termoregulacji w podwzgórzu jest jednym z czynników wywołujących podwyższenie ciepłoty ciała ${ }^{59}$. Jedną z głównych funkcji IL-6 jest inicjacja i regulacja ostrej odpowiedzi zapalnej. Wzmożona produkcja IL-6 promuje przejście ostrej reakcji zapalnej w fazę chroniczną i przyczynia się do powstawania wielu chorób przewlekłych ${ }^{59,60 .}$

IL-6 oprócz indukcji ostrej odpowiedzi zapalnej, wpływa na namnażanie i różnicowanie limfocytów B oraz regulację białek inhibitorowych. Stężenie IL-6 u zdrowych osób młodych jest zwykle bardzo niskie, często niewykrywalne. Wraz z wiekiem stężenie IL-6 wzrasta, a jego stężenie koreluje z nasileniem procesów degeneracyjnych typowych dla wieku zaawansowanego. Wysokie stężenie IL-6 ( $>5 \mathrm{pg} / \mathrm{mL})$ jest wykrywane w wielu chorobach m.in. w chorobach nowotworowych (chłoniakach, szpiczaku, w nowotworach głowy i szyi), w chorobie Alzheimera, reumatoidalnym zapaleniu stawów, osteroporozie itd ${ }^{61}$.

Koenig $\mathrm{i}$ in. (1997), przeprowadzili długotrwałe, trwające 6 lat badanie, mające na celu ocenę wpływu regularnych praktyk religijnych, na stężenie IL-6 ${ }^{62}$. Wartość graniczną IL-6 we krwi obwodowej przyjęto w badaniu określono na $5 \mathrm{pg} / \mathrm{mL}$. Co ciekawe, kiedy porównano osoby regularnie uczestniczące w życiu religijnym do grupy kontrolnej (osób nie biorących udziału w życiu religijnym), osoby religijne miały mniej więcej $50 \%$ szans na niższe niż $5 \mathrm{pg} / \mathrm{mL}$ poziomy IL-6. Wysoka frekwencja i aktywność w życiu religijnym w wyżej wymienionych badaniach miały też wpływ na niższe stężenia markerów zapalnych, jak alfa-2-globulina czy D-dimery. Badacze wykazali słabą zależność między grupą aktywnie uczestni-

A Systematic Review of Transcendent States Across Meditation and Contemplative Traditions. Explore (NY)., 14(1), 19-35. doi: 10.1016/j.explore.2017.07.007.

59 Lydyard, P.M., Whelan, A., Fanger, M.W. (2009). Krótkie wyktady Immunologia. Warszawa: PWN, 27-38.

60 Kontny, E., Maśliński, W. (2009). Interleukin 6 - biological activities and role in rheumatoid arthritis pathogenesis. Reumatologia, 47, 1, 24-33.

61 Tanaka, T., Narazaki, M., Kishimoto, T. (2014). IL-6 in inflammation, immunity, and disease. Cold Spring Harb Perspect Biol., 4;6(10):a016295. doi: 10.1101/cshperspect.a016295.

62 Koenig, H.G., Cohen, H.J., George, L.K., Hays, J.C., Larson, D.B., Blazer, D.G. (1997). Attendance at religious services, interleukin-6, and other biological parameters of immune function in older adults. Int J Psychiatry Med., 27(3), 233-250. czących w życiu religijnym i grupą kontrolną, a stężeniami IL-6 (OR 0,58, 95\% CI 0,40-0,84, p <0,005); którego nie potrafili wythumaczyć innymi zmiennymi (jak depresją lub negatywnymi wydarzeniami życiowymi).

\section{Stopień zaangażowania religijnego a długość telomerów}

W przeciwieństwie do kolistego bakteryjnego DNA, chromosomy eukariotyczne mają wolne końce. Telomery są to krótkie, powtarzające się fragmenty każdego z chromosomów. Zlokalizowane na końcach nici DNA zabezpieczają ją przed uszkodzeniem podczas kopiowania i utratą genów na końcach nici. Telomery skracają się podczas każdego podziału komórkowego. Proces ten, będący „licznikiem podziałów", równocześnie z każdym skróceniem zwiększa ryzyko tworzenia komórek nowotworowych oraz przekłada się na proces starzenia i apoptozę komórkową ${ }^{63}$.

Hill i in. (2016), sprawdzili czy długość telomerów leukocytów jest różna $\mathrm{w}$ zależności od różnych aspektów zaangażowania religijnego. Wykorzystali dane przeprowadzonego w latach 2011-2014 badania Nashville Stress and Health Study. Grupę badaną stanowiły 1252 dorosłe osoby (w wieku 22-69 lat) mieszkające w hrabstwie Davidson w USA. Analizy wykazały, że wysoki wskaźnik obecności religijnej, częstotliwość modlitewna i tożsamość religijna był pozytywnie związany z długością telomerów, a co za tym idzie, z długością życia krwinek białych ${ }^{64}$.

\section{Pacjenci HIV/AIDS, odporność, objawy depresji a ich religijność}

Religia jest pomocą dla niektórych HIV-dodatnich kobiet $\mathrm{w}$ radzeniu sobie $\mathrm{z}$ trudną i stygmatyzującą chorobą. Duchowe praktyki mogą mieć pozytywny wpływ na zdrowie fizyczne i psychiczne. W przekrojowym badaniu Dalmida i in. (2009), powiązali psychiczne samopoczucie z objawami depresji oraz liczbą limfocytów CD4+, wśród nielosowej próby 129 kobiet $\mathrm{w}$ przeważającej mierze afro-amerykanek z HIV ${ }^{65}$. Dobrostan duchowy pacjentek HIV pozytywnych był powiązany ze zmniejszonym odsetkiem depresji. Badanie to było jednym z pierwszych badań mających na celu zidentyfikowanie istotnego związku między duchowością, a statusem odporności u kobiet zakażonych wirusem HIV. Badania te sugerują istnienie związku między dobrostanem psychicznym i lepszym stanem systemu immunologicznego u kobiet zakażonych wirusem HIV. Stwierdzono m.in. wzrost odsetka limfocytów

\footnotetext{
O’Sullivan, R.J., Karlseder J. (2010). Telomeres: protecting chromosomes against genome instability. Nat Rev Mol Cell Biol., 11(3), 171--181. 64 Hill, T.D., Ellison, C.G., Burdette, A.M., Taylor, J., Friedman, K.L. (2016). Dimensions of religious involvement and leukocyte telomerelength. Soc Sci Med., 163, 168-175. doi: 10.1016/j.socscimed.2016.04.032.

65 Dalmida, S.G., Holstad, M.M., DiIorio, C., Laderman, G. (2009). Spiritual well-being, depressive symptoms, and immune status among women living with HIV/AIDS. Women Health., 49(2-3), 119-43. doi: 10.1080/03630240902915036.
} 
T CD4+ u kobiet zakażonych wirusem HIV, u których nie stwierdzano postaw depresyjnych.

\section{Mnisi Świętej Góry Athos a stan ich zdrowia}

Ojcowie pustyni na pytanie: „Co mam czynić, by się zbawić?”, odpowiadali: „Idź za Chrystusem!”. Mnich jest to człowiek, który wierzy, że rezygnując z życia w społeczeństwie będzie kroczyć za Chrystusem aż po kres ziemskiego życia by zjednoczyć się z nim po zakończeniu życia doczesnego. Mnisi od wieków żywili przekonanie, że dusza $i$ ciało to nie dwie rzeczy istniejące obok siebie, lecz ściśle ze sobą współdziałające. Właśnie monastycyzm spowodował wzrost przekonania o wspólnocie duszy i ciała ${ }^{66}$.

Modlitwa trwa w granicach Góry Athos bez przerwy od wieków. Jedną z podstawowych mniszych (nie tylko w tej wspólnocie) powinności jest modlitwa i kontemplacja ${ }^{67}$.

W obrębie republiki mnichów obowiązuje 180-200 dni postu w ciągu roku. Atonici (mnisi z Góry Athos) praktycznie nie chorują na choroby serca, rzadkością są niespodziewane ostre stany kardiologiczne czy udary. Współczynnik zachorowalności na chorobę Alzheimera jest bliski zeru (przekaz ustny za lekarzem i mnichem ze św. Góry Athos, o. Ermolas' ${ }^{68}{ }^{68}$ ). Stan zdrowia mnichów zadziwia naukowców prowadzących różne badania ${ }^{69,70,71}$. Zwracają oni uwagę na niezwykle niskie wskaźniki zachorowalności na raka, w przypadku raka prostaty owe statystyki są nawet 4 razy niższe niż średnia w populacji ${ }^{69}$. W latach 90 -tych ubiegłego wieku prowadzono badania, w których brali udział mnisi w wieku od 50 do 104 lat. W owej grupie zachorowalność na raka płuca, jelita i pęcherza wynosiła blisko zero ${ }^{69},{ }^{70}$.

Karras i in. (2017), opublikowali jak dotąd najobszerniejsze badania dotyczące diety i stanu zdrowia mnichów ze Świętej Góry Athos ${ }^{71}$. Jak wiadomo życie mnicha nierozerwalnie związane jest $\mathrm{z}$ kalendarzem liturgicznym. Zbadano skład diety i jej kaloryczność podczas dni postnych oraz zwykłych. Grupa siedemdziesięciu mnichów (w wieku 38,8 $\pm 9,7$ lat, będacych w stanie mniszym 12,5 $\pm 8,2$ lat) została na wstępie zakwalifikowana pod względem aktywności fizycznej (lekka, umiarkowana czy intensywna) i diety, dalej z tej grupy pięćdziesięciu badanym wykonano analizy antropometryczne oraz testy krwi; skupiono się na markerach metabolizmu układu sercowo-naczyniowego

\footnotetext{
${ }_{66}$ Leloup, J.Y. (2012). Słowa z góry Athos. Duchowość mnichów z góry Athos. Tyniec: Tyniec Wydawnictwo Benedyktynów.

${ }^{67}$ Życie mnicha jest dziełem dla Boga (Mt 19, 21): [...] Jeśli chcesz być doskonały, idź, sprzedaj, co posiadasz, i rozdaj ubogim, a będziesz miał skarb w niebie. Potem przyjdź i choć za Mną!. Modlitwa ma być i jest najważniejszym zadaniem mnicha. Św. Jan Chryzostom powiedział: zawołaj tylko „Panie, zmiłuj się nade mną!” a natychmiast masz łączność z Bogiem.

68 Przekaz ustny z dnia 18.09.2016 za mnichem ojcem Ermolas'em, doktorem medycyny z klasztoru Simonos Petras w obrębie Republiki Mnichów na Półwyspie Athos.

69 Carr, J., Whipple, T. (6 grudnia 2006). A foolproof anti cancer diet... with just one or two drawbacks. The Times [on-line].

70 Katz, N. (8 grudnia 2011). How do Mount Athos Monks stay so healthy? The CBS News [on-line].
}

oraz homeostazie wapniowej. Stwierdzono niskie poziomy przyjmowanych kalorii w codziennej diecie zarówno podczas dni zwykłych $(1660,0 \pm 81,0 \mathrm{kcal})$ jak i postnych (1265,9 $\pm 84,5 \mathrm{kcal})$. Wśród wybranych pięćdziesięciu $\mathrm{w}$ analizach antropometrycznych stwierdzono masę ciała $(74,3 \pm 12,9 \mathrm{~kg})$ oraz wyliczono wskaźnik masy ciała do wzrostu BMI który wynosił $\left(23,8 \pm 4,1 \mathrm{~kg} / \mathrm{m}^{2}\right)$, wskaźnik BMI okazał się bez związku statystycznego z poziomem aktywności fizycznej mnichów. Poziomy glukozy i insuliny były w granicach normy. Zbadano profil lipidowy (cholesterol całkowity, cholesterol HDL i LDL oraz trójglicerydy), który okazał się być optymalny.

Z odchyleń od stanu prawidłowego, wykazano głębokie niedobory witaminy $\mathrm{D}(8,8 \pm 6,2 \mathrm{ng} / \mathrm{mL})^{71}$, która to witamina jest niezbędna w prawidłowym funkcjonowaniu zarówno odporności wrodzonej, jak i nabytej ${ }^{72}$. Mimo powyższego nie stwierdzono zwiększonej zachorowalności na choroby związane z upośledzeniem funkcji układu immunologicznego.

Ojciec Ermolaos, lekarz aktywnie pracujący na rzecz wspólnoty oraz mnich, thumaczy, że owy stan zdrowia mnichów prawdopodobnie wynika z braku używek takich jak papierosy, alkohol czy inne substancje uzależniające w tym też nadużywanie leków; dalej narzeka jednak na fakt wysokiego współczynnika zapadalności na przewlekłą niewydolność żylną spowodowaną długimi i często całonocnymi modlitwami w pozycji stojącej ${ }^{68}$.

Mnisi pozostają w przekonaniu, że stała praktyka Modlitwy Jezusowej (formy medytacji skupiającej się na osobie Jezusa) reguluję i spowalnia częstość pracy serca, a także jest jednym z najważniejszych czynników zachowujących ich w pełni zdrowia ${ }^{68,70}$.

\section{Podsumowanie}

Pomimo upływającego czasu, rozwoju nauk zarówno ścisłych, jak humanistycznych (w tym medycyny i psychiatrii) wciąż istnieje $\mathrm{w}$ człowieku potrzeba kontaktu $\mathrm{z}$ istotą wyższą, z Bogiem. Paradoksem naszych czasów jest fakt, że współczesny człowiek tak wiele wiedząc o fizycznie otaczającym nas świecie, zapomina o sferze duchowej. Łacińskie słowo religio oznacza przywrócenie więzi ${ }^{73}$. Praktyki religijne ( $w$ tym modlitwa) są powszechnymi próbami utworzenia pomostu między postrzegalnym i mierzalnym stanem materii, a doświadczalnym pozazmysłowo światem duchowym.

Modlitwa i jej „efektowność” jest uwarunkowana zarówno ,pracą ziemską" człowieka modlącego się (prośba wyrażona $\mathrm{w}$ modlitwie winna być zharmonizowana

\footnotetext{
${ }^{71}$ Karras, S.N., Persynaki, A., Petróczi, A., Barkans, E., Mulrooney, H., Kypraiou, M., Tzotzas, T., Tziomalos, K., Kotsa, K., Tsioudas, A.A., Pichard, C., Naughton, D.P. (2017). Health benefits and consequences of the Eastern Orthodox fasting in monks of Mount Athos: a cross-sectional study. Eur J Clin Nutr., 71(6), 743-749. doi: 10.1038/ejcn.2017.26.

72 Prietl, B., Treiber, G., Pieber, T.R., Amrein, K. (2013). Vitamin D and Immune Function. Nutrients, 5, 2502-2521.

73 od słowa religare - łączyć, wiązać.
} 
z wolą Bożą), jak i „Boską odpowiedzią” co objawia się w postaci tzw. owoców modlitewnych (Bóg udziela darów wówczas, gdy spełnimy Jego wolę), mogących stanowić np. przywrócenie zdrowia psychicznego czy fizycznego. Wiara i praktyki religijne mają na celu przywrócenie jedności z boskim logos, przywróceniu jedności duszy i ciała. Praktyki religijne zostały wielokrotnie powiązywane z leczeniem wszelakich chorób przez tysiąclecia, a powodując poprawę parametrów fizjologicznych mogą przyczyniać się do faktycznej poprawy zdrowia człowieka ${ }^{55,56}$. Stwierdzono m.in., że medytacja transcendentalna $\mathrm{z}$ dominacją mistyczną daje znaczące efekty prozdrowotne ${ }^{55-57}$.

Modlitwa może wpływać na funkcjonowanie organizmu za pomocą różnych mechanizmów. Autorzy wielu publikacji ${ }^{37,42,43,45-49,54-65}$ dowodzą, że religia, modlitwa i praktyki religijne mają istotny wpływ w regulowaniu układu autonomicznego, hormonalnego oraz psychiki. Osoby religijne rzadko wykazują nieprawidłowe wahania $\mathrm{w}$ aktywności układu autonomicznego, wydaje się więc, że stabilność układu autonomicznego jest u nich większa. Osoby praktykujące rzadziej chorują na choroby powodowane nadmiernym stresem (związane z uwalnianiem nadmiernej ilości hormonów stresu). W dotychczas przeprowadzonych badaniach naukowych znaleziono dowody na istnienie ko- rzystnej korelacji pomiędzy uprawianiem praktyk religijnych, a np. stężeniem IL-6, długością telomerów, liczbą limfocytów T CD4+ oraz depresją ${ }^{62-65}$. Wydaje się prawdopodobne, że osoby oddające się praktykom religijnym mogą charakteryzować się mniejszą częstością niektórych chorób somatycznych.

Wyniki w/w badań sugerują potrzebę ponownego otwarcia się na inne, nie tylko „somatyczne” formy terapii, które w umiejętny i zindywidualizowany sposób powinny uzupełniać podstawowe metody terapii stosowane aktualnie. Pracownicy ochrony zdrowia oprócz baczniejszego zwrócenia uwagi na duchowe tło istniejących zaburzeń somatycznych, powinni ściślej współpracować z psychologami, psychiatrami i duchownymi, w celu skoordynowania holistycznego podejścia do zindywidualizowanej opieki nad pacjentem, które powinno obejmować także aspekty duchowości ${ }^{74}$.

\section{„Modlitwa daje więcej niż Czlowiek zamarzy.” (Alfred Lord Tennyson, od Morte d'Arthur) \\ „Wiara może góry przenosič". (Biblia, parafraza z Mateusza 21:21)}

74 Ostaszewska, A. (2014). Badania nad efektywnościa włączania tematyki duchowości i religijności w psychoterapii. Psychoterapia, 2(169), 5.

\section{Bibliografia}

Al-Ayadhi, L.Y. (2005). Neurohormonal changes in medical students during academic stress. Ann Saudi Med., 25(1), 36-40.

Ałfiejew, H. (2009). Misterium wiary. Wprowadzenie do Prawostawnej teologii dogmatycznej. Warszawa: Warszawska Metropolia Prawosławna, 223.

Anderson, J.W., Liu, C., Kryscio, R.J. (2008). Blood pressure response to transcendental meditation: a meta-analysis. Am J Hypertens, 21(3), 310-366. doi: 10.1038/ajh.2007.65.

Andrade, C., Radhakrishnan, R. (2009). Prayer and healing: A medical and scientific perspective on randomized controlled trials. Indian J Psychiatry, 51, 247-253.

Barnes, V.A., Davis, H.C., Murzynowski, J.B., Treiber, F.A. (2004). Impact of meditation on resting and ambulatory blood pressure and heart rate in youth. Psychosom Med., 66(6), 909-914.

Breen, M.S., Beliakova-Bethell, N., Mujica-Parodi, L.R., Carlson, J.M., Ensign, W.Y., Woelk, C.H., Rana, B.K. (2016). Acute psychological stress induces short-term variable immune response. Brain Behav Immun., 53, 172-182. doi: 10.1016/j.bbi.2015.10.008.

Cahill, S.P., Pontoski, K. (2005). Post-Traumatic Stress Disorder and Acute Stress Disorder I: Their Nature and Assessment Considerations. Psychiatry (Edgmont), 2(4), 14-25.

Carr, J., Whipple, T. (6 grudnia 2006). A foolproof anti cancer diet... with just one or two drawbacks. The Times [on-line].

Chuengsatiansup, K. (2003). Spirituality and health: an initial proposal to incorporate spiritual health in health impact assessment. Environmental Impact Assessment Review, 23, 3-15.

Collingwood, J. (2016). How Does Mood Affect Immunity?. Psych Central. Retrieved on March 15, 2017.
D'Acquisto, F. (2017). Affective immunology: where emotions and the immune response converge. Dialogues in Clinical Neuroscience, 19(1), 9-19.

Dalmida, S.G., Holstad, M.M., DiIorio, C., Laderman, G. (2009). Spiritual well-being, depressive symptoms, and immune status among women living with HIV/AIDS. Women Health., 49(2-3), 119-43. doi: 10.1080/03630240902915036.

Davidson, R.J., Kabat-Zinn, J., Schumacher, J., Rosenkranz, M., Muller, D., Santorelli, S.F., Urbanowski, F., Harrington, A., Bonus, K., Sheridan, J.F. (2003). Alterations in brain and immune function produced by mindfulness meditation. Psychosom Med., 65(4), 564-570.

Evdokimov, P. (1986). Prawosławie. Warszawa: Instytut Wydawniczy PAX, 81-84.

Evdokimov, P. (1986). Prawosławie. Warszawa: Instytut Wydawniczy PAX, 146-148.

Evdokimov, P. (1986). Prawostawie. Warszawa: Instytut Wydawniczy PAX, 118.

Heszen-Niejodek, I., Gruszczyńska, E. (2004). Wymiar duchowy człowieka, jego znaczenie w psychologii zdrowia i jego pomiar. Przegląd psychologiczny, 47(1), 15-31.

Hill, T.D., Ellison, C.G., Burdette, A.M., Taylor, J., Friedman, K.L. (2016). Dimensions of religious involvement and leukocyte telomere length. Soc Sci Med., 163, 168-175. doi: 10.1016/j. socscimed.2016.04.032.

Irving, W., Ala'Aldeen, D., Boswell, T. (2005). BIOS Instant notes in Medical Microbiology. New York: Taylor and Francis Group, 9-17.

Jakimiuk, M. (red.) (2016). Święty starzec Paisjusz HagiorytaStowa wybrane fragmenty. Hajnówka: Bratczyk. 
Jaworek, J., Leja-Szpak, A., Nawrot-Porąbka, K., Szklarczyk, J., Kot, M., Pierzchalski, P., ... Bonior, J. (2017). Effects of Melatonin and Its Analogues on Pancreatic Inflammation, Enzyme Secretion, and Tumorigenesis. International Journal of Molecular Sciences, 18(5), 1014. http://doi.org/10.3390/ ijms18051014.

Karras, S.N., Persynaki, A., Petróczi, A., Barkans, E., Mulrooney, H., Kypraiou, M., Tzotzas, T., Tziomalos, K., Kotsa, K., Tsioudas, A.A., Pichard, C., Naughton, D.P. (2017). Health benefits and consequences of the Eastern Orthodox fasting in monks of Mount Athos: a cross-sectional study. Eur J Clin Nutr., 71(6), 743-749. doi: 10.1038/ejen.2017.26.

Katz, N. (8 grudnia 2011). How do Mount Athos Monks stay so healthy? The CBS News [on-line].

Kiecolt-Glaser, J.K., Malarkey, W.B., Chee, M., Newton, T., Cacioppo, J.T., Mao, H.Y., Glaser, R. (1993). Negative behavior during marital conflict is associated with immunological down-regulation. Psychosom Med., 55(5), 395-409.

Kjaer, T.W., Bertelsen, C., Piccini, P., Brooks, D., Alving, J., Lou, H.C. (2002). Increased dopamine tone during meditation-induced change of consciousness. Brain Res Cogn Brain Res., 13(2), 255-259.

Koenig, H.G., King, D.A., Carson, V.B. (2012). Handbook of Religion and Health. New York: Oxford University Press, 15.

Koenig, H.G., King, D.A., Carson, V.B. (2012). Handbook of Religion and Health. New York: Oxford University Press, 396.

Koenig, H.G., Cohen, H.J., George, L.K., Hays, J.C., Larson, D.B., Blazer, D.G. (1997). Attendance at religious services, interleukin-6, and other biological parameters of immune function in older adults. Int J Psychiatry Med., 27(3), 233-250.

Kontny, E., Maśliński, W. (2009). Interleukin 6 - biological activities and role in rheumatoid arthritis pathogenesis. Reumatologia, 47, 1, 24-33.

Leloup, J.Y. (2012). Słowa z góry Athos. Duchowość mnichów z góry Athos. Tyniec: Tyniec Wydawnictwo Benedyktynów.

Lydyard, P.M., Whelan, A., Fanger, M.W. (2009). Krótkie wyktady Immunologia. Warszawa: PWN, 27-38.

McEwen, B.S. (2007). Physiology and neurobiology of stress and adaptation: central role of the brain. Physiol Rev., 87(3), 873-904.

McEwen, B.S., Stellar, E. (1993). Stress and the individual: Mechanisms leading to disease. Archives of Internal Medicine, 153, 2093-2101.

O'Sullivan, R.J., Karlseder, J. (2010). Telomeres: protecting chromosomes against genome instability. Nat Rev Mol Cell Biol., 11(3), 171-181.

Ostaszewska, A. (2014). Badania nad efektywnościa włączania tematyki duchowości i religijności w psychoterapii. Psychoterapia, 2(169), 5.

Paloutzian, R.F., Park, C.L. (2005). Handbook of the psychology of religion and spirituality. New York: Guilford Press, 12.

Pandi-Perumal, S. R., BaHamman, A. S., Spence, D. W., Brown, G. M., Bharti, V. K., Kaur, C., Hardeland, R., Cardinali, D. P. (2012). Melatonin antioxidative defense: therapeutical im- plications for aging and neurodegenerative processes. Neurotoxicity Research, 23(3), 267-300.

Peale, N.V. (2002). Moc pozytywnego myślenia. Warszaw: Wydawnictwo Studio Emka, 54-70.

Permoda-Osip, A., Rybakowski, A. (2011). Rola układu glutaminergicznego $w$ mechanizmie działania przeciwdepresyjnego $i$ normotymicznego w chorobach afektywnych. Farmakoterapia w psychiatrii i neurologii, 2, 57-65.

Pietkiewicz P. (2016). Wspótpraca kapłana i psychiatry w celu przywrócenia zdrowia człowieka. Elpis, 18, 133-136.

Prietl, B., Treiber, G., Pieber, T.R., Amrein, K. (2013). Vitamin D and Immune Function. Nutrients, 5, 2502-2521.

Salomon, E.P., Berg, L.R., Martin, D.W. (2009). Biologia. Warszawa: Multico, 831-856.

Schwartz, S.A., Dossey, L. (2010). Nonlocality, intention, and observer effects in healing studies: laying a foundation for the future. Explore (NY)., 6(5), 295-307. doi: 10.1016/j. explore.2010.06.011.

Śliwerski, B. (2007). Samowychowanie jako odrodzenie moralne. Przegląd pedagogiczny, (1), 15-34.

Solberg, E.E., Ekeberg, O., Holen, A., Ingjer, F., Sandvik, L., Standal, P.A., Vikman, A. (2004a). Hemodynamic changes during long meditation. Appl Psychophysiol Biofeedback, 29(3), 213-221.

Solberg, E.E., Holen, A., Ekeberg, Ø., Østerud, B., Halvorsen, R., Sandvik, L. (2004b). The effects of long meditation on plasma melatonin and blood serotonin. Med Sci Monit., 10(3), 96-101.

Świderkówna A. (tłum.). (2002). Św. Augustyn. Dialogi duszy. Kraków: Znak.

Tanaka, T., Narazaki, M., Kishimoto, T. (2014). IL-6 in inflammation, immunity, and disease. Cold Spring Harb Perspect Biol., 4;6(10):a016295. doi: 10.1101/cshperspect.a016295.

Turzyński, P. (2015). Antropologia trychotomiczna Orygenesa. VOX PATRUM, 63, 35-46.

Wachholtz, A.B., Pargament, K.I. (2005). Is spirituality a critical ingredient of meditation? Comparing the effects of spiritual meditation, secular meditation, and relaxation on spiritual, psychological, cardiac, and pain outcomes. J Behav Med., 28(4), 369-384.

Wachholtz, A.B., Pargament, K.I. (2008). Migraines and meditation: does spirituality matter? J Behav Med., 31(4), 351-366. doi: 10.1007/s10865-008-9159-2.

Wahbeh, H., Sagher, A., Back, W., Pundhir, P., Travis, F. (2018). A Systematic Review of Transcendent States Across Meditation and Contemplative Traditions. Explore (NY)., 14(1), 19-35. doi: 10.1016/j.explore.2017.07.007.

Wolański, N. (2012). Rozwój biologiczny człowieka. Podstawy auksologii, gerontologii $i$ promocji zdrowia. Warszawa: PWN, 436-445.

Woźniak, B. (2015). Zaangażowanie religijne a zdrowie w starości Mechanizmy zależności, wybrane wyniki badań. Kraków: Wydawnictwo Uniwersytetu Jagiellońskiego.

Rozmiar artykułu: 1,47 arkuszy wydawniczych 


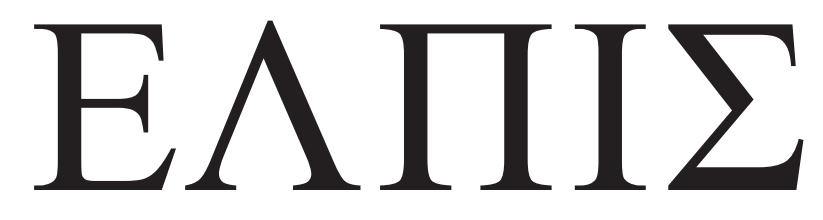

CZASOPISMO TEOLOGICZNE KATEDRY TEOLOGII PRAWOSŁAWNEJ UNIWERSYTETU W BIAŁYMSTOKU

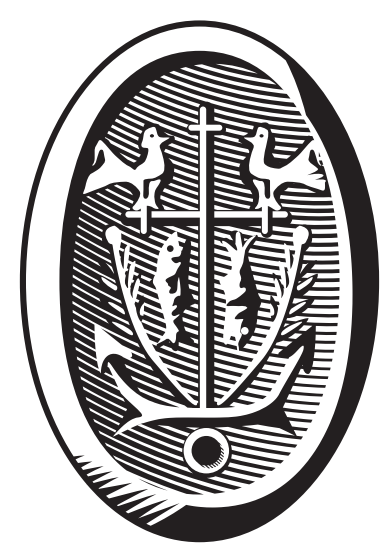

ADRES REDAKCJI

ul. Ludwika Zamenhofa 15, 15-435 Białystok, Polska tel. 85 745-77-80, e-mail: elpis@uwb.edu.pl www.elpis.uwb.edu.pl 